\title{
Implementation of Online Auction (E-Auction) in the State and Auction Service Office
}

\author{
Nabila Noviandra ${ }^{1 *}$, Marjo $^{2}$, KartikaWidya Utama $^{3}$ \\ \{nabnov99@gmail.com ${ }^{* 1}$, marjo.fh.undip@gmail.com ${ }^{2}$, kartikawidyautama@yahoo.co.id ${ }^{3}$ \} \\ Fakultas Hukum, Universitas Diponegoro, Semarang, Indonesia ${ }^{1,2,3}$
}

\begin{abstract}
In order to provide optimal services for auction service users of the Office of State Assets and Auction Services (KPKNL), the Directorate General of State Assets under the auspices of the Ministry of Finance of the Republic of Indonesia built an internet-based auction implementation system called Electronic Auction (E-Auction) that is applied to KPKNL throughout Indonesia including the Semarang City KPKNL. The purpose of this study is to determine the reasons for the implementation of e-auction at the Semarang City KPKNL, to know the procedure for submitting e-auction applications at the Semarang City KPKNL, and to know the obstacles in implementing the e-auction at the Semarang City KPKNL and the efforts to overcome them. The method used by the author is normative juridical. The data analysis method used is descriptive qualitative. The study was conducted at the Semarang City KPKNL.The results of the study found that all e-auction application submission activities are carried out through the Indonesian Auction Portal either through the website or the application on android which requires users to have an account at the Indonesian Auction Portal to submit an e-auction application - as well as being an e-auction participant. Where implementing, there were still some obstacles that came from external and internal factors, however, the City of Semarang KPKNL continued to make efforts to overcome these obstacles.
\end{abstract}

Keywords: Online Auction, Auction Applicant, Office of State Assets and Auction Services, Indonesian Auction Portal.

\section{Introduction}

General sales have officially been regulated into legislation in Indonesia since 1908, marked by the enactment of VenduReglement (Regulation of Stl. 1908 Number 189), VenduInstructie (Auction Instructions of Stl. 1908 No. 190). The auction rules as a colonial legacy still apply. Auction is known as a named agreement (nominaat)/special agreement (benoemnd) because the agreement has its own name, "auction", and is regulated and named by the legislators, this is mentioned in the Vendor Regalement. The auction is specifically regulated outside the Civil Code (Civil Code). Auctions are generally a means of bringing together sellers and buyers with the aim of determining a fair price for an item. [1] The auction is carried out with special provisions in the Civil Execution Law. Changes have occurred in the auction, both the principles contained in the regulations, the auction institution itself and the changes in the auction process. There are at least three purposes for regulating auctions in law, namely:

1. To meet the needs of auction sales, which are regulated by many laws and regulations. 
2. To meet or implement judicial decisions or dispute resolution institutions based on the law in the context of upholding justice (law enforcement).

3. To meetthe needs of the business community in general, it is possible for producers or owners of personal goods to sell at auction.

Then, there are the principles underlying the implementation of the auction of sale of goods, namely, first, the Transparency Principle, which means that openness is the most important principle that builds auction rules, nothing is hidden, the public is treated equally to compete in buying goods at auction. Second is the Principle of Certainty which includes certainty related to whether or not the auction will be carried out, related to the place of the auction, and related to the guarantee money that has been paid by prospective buyers if the auction does not happen or is canceled. The third is the Principle of Competition which means that bidders participate in this auction by competing to achieve the price desired by the seller of goods. The fourth is the Principle of Efficiency, namely the implementation of the auction must pay attention to the timeliness, and practicality of the location of the auction so that the auction can be carried out in an orderly and not protracted. The last or fifth is the Principle of Accountability, namely the auction must be held accountable, the auction must be carried out by the authorized official and in an appropriate location according to the applicable laws and regulations.

In Indonesia, auctions are carried out both by the State Assets and Auction Services Office (KPKNL) and the privately owned Auction Hall. The Office of State Assets and Auction Services (KPKNL) is a vertical agency of the Directorate General of State Assets under and directly responsible to the Head of the Regional Office of the Directorate General of State Assets, while the Regional Office itself is directly responsible to the Director General of State Assets (DJKN) under the auspices of Ministry of Finance whose provisions are regulated in Minister of Finance Regulation No. 170/PMK.01/2012 Organization and Work Procedures of the Vertical Agency of the Directorate General of State Assets.[2]

The current auction is regulated under Minister of Finance Regulation No. 27/PMK.06/2016 2016 concerning Bidding Implementation Guidelines.[3] When this Ministerial Regulation comes into force, the Minister of Finance Regulation Number 93/PMK.06/2010 concerning Bidding Implementation Guidelines as amended by Minister of Finance Regulation Number 106/PMK.06/2013, is revoked and declared invalid.

Minister of Finance Regulation No. 27/PMK.06/2016 regulates matters related to auctions, such as the auction must be carried out by and/or in front of the Bidding Officer unless the Law or Government Regulation stipulates otherwise, when the auction is held, Auction Minutes must be made, auctions which carried out in accordance with applicable provisions cannot be canceled, the type of auction consisting of an Execution Auction, Mandatory Non-Execution Auction, and Voluntary Non-Execution Auction, and the Head of the Office of State Assets and Auction Services (KPKNL) and Class II Auction Officers are not permitted to refuse an auction application if the application has already been fulfill the legal requirements of the subject and object. Regulation of the Minister of Finance No. 27/PMK.06/2016 divides the auction into 3 separate classifications namely Execution Auction, Mandatory Non-Execution Auction and Voluntary Non-Execution Auction.

In today's era of globalization it cannot be denied that technology has developed rapidly. The development of technology in various aspects would also have an impact on human life, ranging from communication, daily life, which all becomes more practical because of the development of technology. One aspect affected by globalization is the service aspect in the field of Government, almost all government platforms now have websites and social media as 
a way to facilitate access for the community. The advantage of this technological development is used by most people to make transactions via the internet, because it is more efficient and cost-effective.

The Directorate of Auction with the Directorate of State Assets Management and Information Systems initiated an online auction application facility (e-auction) to provide convenience services from the Auction Applicant (seller) side and the Office of State Assets and Auction Services (KPKNL)[4].

The development of the auction through the internet is inseparable from the many problems that occur at this time, in 2014, the Directorate General of State Assets also initiated the implementation of the Online Auction by launching an Electronic Auction Management Information System (SMILE). However, in its implementation, SMILE is still difficult to understand by the wider community because the community still lacks info on the existence of a website to participate in this auction. So that the auction process experienced innovation in 2018. DJKN updated the online auction system to be more user friendly and can run the auction process quickly with a new website namely http://lelang.go.id and this online auction system is a contemporary auction that relies on connections internet in the auction process.

Arrangements regarding internet auction or e-auction previously did not exist in the VenduReglement and Instructie Vendors which were the basis for the auction arrangement in the past, but along with the development of the era and technology, now e-auction has been known and started to be sought after by the wider community, so that a new regulation regarding auctions was issued which also regulates e-auction.

Online auction (e-auction) is explained in the Regulation of the Minister of Finance of the Republic of Indonesia No. 90/PMK.06/2016 Concerning Guidelines for Implementing Bidders with Written Bidding without Bidders Attending Via the Internet. According to Article 1 Number 1, Regulation of the Minister of Finance of the Republic of Indonesia No. 90/PMK.06/2016 Concerning Guidelines for Implementing Bidders with Written Bidding without the Attendance of Bidders Via the Internet, online Auction (e-auction), namely:[5]

"Auction with Written Bidding without the presence of Bidders through the Internet, hereinafter referred to as Internet Auction, is the sale of goods open to the public with a written bidding price without the presence of bidders to reach the highest price, which is done through an internet-based auction application."

With the new regulation, the media for conducting the auction will be expanded. Auction is no longer just selling goods that are open to the public directly, but indirectly through electronic/internet media. As a new breakthrough in the civil execution system, namely auction sales, it does not mean this online auction (e-auction) has no loopholes for shortages. Because the system is not perfect, sometimes this unstable system can be detrimental to bidders.

Based on the description above, the authors formulated several key issues to be examined, namely as follows:

1. Why must be an online auction (e-auction) in the sale of goods at the Office of State Assets and Auction Services (KPKNL) Semarang?

2. What is the procedure for submitting an online auction (e-auction) in the sale of goods at the Semarang Office of State Assets and Auction Services (KPKNL)?

3. What are the obstacles in implementing an online auction (e-auction) at the Semarang Office of State Assets and Auction Services (KPKNL), and how are efforts to overcome these problems? 


\section{Research Methods}

The method of approach used in this study is Normative Juridical Method. The research specifications used to strengthen the legal research process are descriptive analysis studies, because they only describe the object of the problem which is then analyzed and finally drawn conclusions from the results of the research.

This primary data can be obtained from auction officials who will be interviewed related to the online auction of the sale of goods, as well as the participants of the online auction of selling goods both sellers and buyers, who follow the online auction process organized by the Semarang City KPKNL. Secondary data for legal journals is obtained from library data or better known as legal material, such as binding and complementary laws and regulations.

The method used to analyze the data used in this research is descriptive qualitative, because the expected research results are analytical descriptive, that is the results derived from quality data and are relevant to the research material.

\section{Results and Discussion}

\subsection{Reasons for Online Auction (E-Auction) at the Office of State Assets and City Auctions Semarang}

The development of the times and the increasingly high mobility of the community resulted in all matters in daily activities of the community are also required to be more practical in order to support community mobility. Therefore, the auction is designed to be easier and can be followed by everyone wherever located. Then an innovation arose to make the auction more practical and easier for the public so that it attracted many interested people, thereby causing the auction to be carried out using digital media and named e-auction or online auction. After the issuance of PMK No.90/PMK.06/2016 concerning Guidelines for Implementing Auctions with Written Bids without the presence of Bidders via the Internet, the online auction was implemented at the Semarang City KPKNL based on directions from the Head Office and the Minister of Finance to innovate in relation to the auction sale of goods at the Semarang City KPKNL. The current digital era encourages a person to do work easily and thoroughly and in the shortest possible time, so that the effectiveness and efficiency in doing a job is very calculated.

According to DanyKuryanto, Semarang Municipal KPKNL Expert Auction Officer, the online auction itself was held with the aim to simplify and shorten the process of conducting the auction, because buyers do not have to be present directly when conducting auctions. Buyers can simply monitor through the official application of the Indonesian Auction and through the official website of the Directorate General of State Assets (DJKN) for the implementation of online auctions namely www.lelang.go.id. Indonesian Auction Application and websitewww.lelang.go.id is the official DJKN application, which is a place for online auction organizers, both KPKNL and Private Auction Centers.[6] Online auctions are held to mitigate risk[7], because all this time the auction is always identical to anarchist, because usually the debtor does not want to surrender his assets voluntarily.Then avoid the risk of suspicion that the auction can be arranged, because if carried out online all depends on the system, the auction winner is determined automatically by the system based on the amount highest bid. 
The public is now increasingly encouraged to become more familiar with online auctions, and people are introduced to the advantages and benefits of taking part in online auctions. Moreover, the Semarang City KPKNL also slowly began to replace the conventional auction by requiring all applications to be submitted online. This certainly encourages an increase in the frequency of e-auction implementation in the Semarang City KPKNL.

The reasons for conducting online auctions at KPKNL are very diverse, beginning with the increasingly high mobility of the people and rapid technological advances, demanding that everything be done effectively and efficiently. Therefore, the Minister of Finance directs the auction to be carried out online which is then followed up by the Director of the Auction of DJKN by issuing the DJKN Auction Director's Office Note Number ND-1284/KN.7/2019 dated August 21, 2019 regarding Implementation of Online Auction Applications. The online auction aims to facilitate and make comfortable both the applicant and the auction participant. The auction is carried out online in essence to develop the implementation of the auction to be more modern, effective and efficient so that the public does not consider the auction to be difficult and can be manipulated, as well as increasing the confidence of auction users in the performance of the KPKNL Semarang City.

\subsection{Procedure for Submitting Online Auctions at the Office of State Assets and Auction Services (KPKNL) Semarang City}

Submission of tender applications to the Semarang City KPKNL is done online. Applicants will submit online auctions using the official website of the Directorate General of State Assets (DJKN) through the domain addresswww.lelang.go.id, and it can also be accessed through an application located on the Play Store specifically on Android called Lelang Indonesia.[7]Based on information from the Class 1 Auction Officer at the Semarang City KPKNL, before submitting an online auction application through the Indonesian Auction application or through the website www.lelang.go.id, an auction applicant is required to fulfill several requirements, namely:

1. Register as a user/user on the application and the Indonesian Auction website.

2. Upload photos or scan results of Identity Card (KTP). Then the ID card will be examined by the appointed Bidding Officer.

3. Register a Taxpayer Identification Number (NPWP) through the Indonesian Auction Portal, which will then be verified automatically by the Directorate General of Taxes.

4. Register the account number of the auction applicant that is used when the KPKNL will deposit the net results of the auction if the auction is sold.[8]

Then, the auction applicant submits an auction request through the Indonesian Auction Portal by submitting a new auction request, then the type of auction that will be submitted to KPKNL, the types of auctions that can be submitted to KPKNL are Execution Auction, Mandatory Non-Execution Auction and Voluntary Non-Execution Auction. Applicants who have determined the type of auction will be directed to choose the type of transaction, to sell the goods, the selected object is the sale/auction lot, then all information that has been entered is saved so that the data will be stored on the Indonesian Auction Portal server. Once the data has been uploaded, the applicant will be directed to complete the form through the Indonesian Auction Portal. This form will contain the method for submitting net auction results, the identity of the online auction applicant and selecting the Semarang City KPKNL as the party conducting the auction, then choosing the status of the auction object. The identity of the 
auction applicant is filled in using the identity and identity number of the auction applicant, it can be from the Resident Identity Card, Driving License, or Employee Identification Number.

Auction applicants are also required to add objects to the auction, namely an explanation of the items to be sold through an auction, which includes:

1. Location of goods to be sold through auction;

2. The limit value, which must be filled with numbers;

3. Security deposit, in the range of a minimum of $20 \%$ to a maximum of $50 \%$ of the specified limit value;

4. Nature of goods, goods to be auctioned in the form of movable property, immovable property, and intangible goods.

After all relevant data has been entered, the bidder must upload a 4-sided photograph, i.e. from the front, back side, right side and left side of the item to be auctioned. This photo is used for object data purposes that will be offered through the Indonesian Auction Portal.

Before uploading these documents, if the tender applicant is an organization/business entity, it must first be ensured that there is a power of attorney from the head of the organization concerned to delegate this online auction registration to the head of the relevant section of the agency to conduct the auction. So that the application made has clear legal documents and can be used as strong evidence.[8] Auction applicants will be directed to complete data regarding online auction applications through the Indonesian Auction Portal. If the previous process has been saved and successfully uploaded to the Indonesian Auction Portal server, the auction applicant must verify that the uploaded documents are correct and can be accounted for, then the auction applicant must select the submit button so that all data and verification that has been done can be uploaded to the Indonesian Auction Portal server.

Online applications that have been sent to the Semarang City KPKNL will be followed by a verification process by the Semarang City KPKNL officer related to the completeness and suitability of the data uploaded by the auction applicant. If it is complete and appropriate, the application status will change to Digital Document Compliance.[7]

According to respondents from Central Java BPD and BPR GunungRizki, the Petitioner still had to send physical documents to the Semarang City KPKNL via Pos Indonesia or submit them directly to the Semarang City KPKNL officer.[8] After the documents are declared complete and appropriate, the physical documents are sent by including the tickets that have been printed directly through the Indonesian Auction Portal.[9] Physical documents that have been sent to the Semarang City KPKNL will be checked for compliance with documents that have been uploaded online through the Indonesian Auction Portal, when they are complete, the status of the tender application will change to Physical Documents. The city of Semarang sets an auction schedule. The auction determination letter can be downloaded through the Indonesian Auction Portal.

When the auction determination has been issued by the Semarang City KPKNL, the auction applicant is required to make the auction announcement. Pursuant to Article 53 of PMK No.27/PMK.06/2016 concerning the Bidding Implementation Guidelines, auction announcements are carried out through newspapers/daily newspapers which are published daily at the place where the auctioned goods are located.

The first announcement was made with brochures posted at strategic locations. [8] The second announcement was made by advertising in a local newspaper. Every 1 (one) newspaper can only be included 1 (one) request.[9] In the announcement made by the auction applicant the object to be auctioned must be listed along with the data that is to explain the object (for example the auction is a house, then the area of the land and building area are 
mentioned), the time of the e-auction (based on server) and location auction namely websitewww.lelang.go.id and the Indonesian Auction application on android.

If all announcements have been made, the auction applicant is just waiting for the auction to be held, which is based on server time (West Indonesia Time).

\subsection{Obstacles in the Implementation of E-Auction and Efforts to Overcome the Obstacles}

\subsubsection{Obstacle}

Online auctions have obstacles in terms of the system, the organizer, and the regulations. The online auction system that has not been maximized causes maintenance to keep the system running normally, but sometimes it hinders the process of conducting the auction, while the obstacles of the e-auction organizers namely the Semarang City KPKNL are the personnel whose numbers are less for the increasing number of requests each year, according to RoestamArifianto as the Semarang City KPKNL Class I Auction Officer this is due to the frequent rotation of the Auction Officer at the Semarang City KPKNL, which results in a new Auction Officer having to undergo an adaptation beforehand to maximize his work in the Semarang KPKNL environment.

The regulations regarding auction announcements stated in Article 51 of PMK No. 27/PMK.06/2016 concerning Bid Implementation Guidelines that require the auction to also be announced through local newspapers, causing the cost for the auction process to be even higher because if the auction e-auction announcement must be one column for only one application. While, the external obstacle of the online auction is the lack of public knowledge and interest in this online auction, so people tend to be lazy to take part in online auctions because it is considered difficult, because to be an auction applicant must upload digital documents, and still have to send physical documents too, to people old lay people certainly have difficulty implementing it due to limited knowledge of technology, and also not knowing the existence of this online auction which causes the lack of auction buyers.

\subsubsection{Effort}

Efforts that can be carried out by e-auction organizers of the Semarang City KPKNL are by requiring auction applications to be submitted online, adding officers at the Semarang City KPKNL to support the effectiveness and efficiency of the online auction, and allowing announcements with local newspapers to be adjusted to the number of requests submitted to the Semarang City KPKNL to save the costs. As an e-auction organizer, Semarang City KPKNL is also expected to be able to make an effort to disseminate information about the Indonesian Auction Portal, both through the website and with the Indonesian Auction application that can be downloaded at the Play Store specifically available for devices with an Android-based operational system to attract more Buyer.

\section{Conclusion}

1. The first reason for launching an online auction at the Semarang City KPKNL is the demands of globalization and growing technology.It attracts the DJKN to optimize services to the public in relation to the auction. 
2. The main procedure for applying for an online auction at the Semarang City KPKNL is that the applicant must initially have an account at the Indonesian Auction Portal, then meet all the requirements submitted by the websitewww.lelang.go.id.

3. The obstacles in conducting online auctions originate from external and internal factors. The internal factors come from the auction system, auction organizers, and auction rules; while the external factors come from the participants and applicants of the auction itself.

\section{Suggestion}

1. The government is expected to improve the infrastructure that supports the implementation of online auctions throughout the KPKNL so that online auctions can be implemented throughout Indonesia.

2. Semarang City KPKNL as an online auction organizer is expected to add personnel to balance the number of requests that come in so that the auction determination does not take long time to issue, and instead to provide a time limit for issuing auction stipulations so that all can be uniform and not delayed.

3. Bidding Officers are expected to be more proactive and comply with the deadline for the issuance of Bid Determination so that the online auction at the Semarang City KPKNL can be orderly and smoothly implemented.

4. The public who is the online auction petitioner requesting online auction at the Semarang City KPKNL should prepare the required documents in proper, and ensure the validity of the auction object as their own.Therefore, the process of issuing the auction determination can be shortened because the data is directly in accordance between digital documents and documents physical. 


\section{References}

[1] R. Soemitro, Peraturan dan Instruksi Lelang. Bandung: Eresco, 1987.

[2] Minister of Finance Regulation No. 170/PMK.01/2012 concerning Organization and Work Procedures of the Vertical Agency of the Directorate General of State Assets. .

[3] Minister of Finance Regulation No. 27/PMK.06/2016 2016 concerning Bidding Implementation Guidelines. .

[4] Direktorat Jenderal Kekayaan Negara Kementerian Keuangan Republik Indonesia, "Lelang Indonesia." [Online]. Available: https://lelang.go.id/. [Accessed: 03-Nov2019].

[5] Minister of Finance Regulation No. 90/PMK.06/2016 concerning Guidelines for Implementing Bidders with Written Bids without Bidders Attending via the Internet. .

[6] Interview with Dany Kuryanto, Class I Auction Officer of the Semarang City State Assets and Auction Services Office (KPKNL). (Semarang City KPKNL, December 16, 2019). .

[7] Interview with Roestam Arifianto, Class I Auction Officer of the Semarang City State Assets and Auction Service Office (KPKNL) (KPKNL Semarang City, 26 December 2019). .

[8] Interview with Sumiarso, Head of Collection Division at BPR Gunung Rizki Pusaka Utama. (Semarang: Kantor Pusat BPR Gunung Rizki, January 20, 2020). .

[9] Interview with Agus, Central Java BPD ARPK Team (Semarang: Kantor Pusat BPD Jawa Tengah, 17 January 2020). . 